\title{
PERBANDINGAN HASIL AGREGASI TROMBOSIT TANPA PENGENCERAN DAN DENGAN PENGENCERAN SPESIMEN 1:1 DI RUMAH SAKIT PREMIER BINTARO
}

\author{
Hadi Susanto ${ }^{1)}$, Yune Yohana ${ }^{2)}$, Dewi Kurniati ${ }^{3)}$ \\ Program Studi Analis Kesehatan, Fakultas Kesehatan, Universitas Mohammad Husni Thamrin \\ RS PMI Bogor \\ RS Premier Bintaro \\ Correspondence author: Yune Yohana, yune.abbas@yahoo.com, Jakarta, Indonesia
}

\begin{abstract}
ABSTRAK
Frekuensi kematian akibat penyumbatan pembuluh darah di otak dan jantung yang meningkat dari tahun ke tahun. Salah satu faktor terpenting yang berperan dalam proses penyumbatan tersebut adalah thrombosis. salah satu cara untuk menilai fungsi trombosit tersebut adalah dengan pemeriksaan agregasi trombosit. Tujuan dari penelitian ini adalah Mengetahui hasil tes agregasi trombosit dengan pengenceran spesimen 1:1 menggunakan $\mathrm{NaCl}$ fisiologis. Metode Penelitian ini dilakukan dengan cara melakukan pemeriksaan Agregasi trombosit dari spesimen tanpa pengenceran dan dengan pengenceran metode turbiditimetri Hasil Penelitian : Analisa menggunakan uji Paired sampel tes Sig. (2-tailed) $<0.05$ yang menunjukan perbedaan dari hasil tanpa pengenceran dan dengan pengenceran. Terdapat adanya perbedaan hasil dari penelitian sehingga tidak dianjurkan untuk melakukan pengenceran pada pemeriksaan Agregasi trombosit.
\end{abstract}

Kata kunci : Agregasi trombosit,Tanpa pengenceran, Pengenceran

\section{ABSTRACT}

The frequency of death due to blockage of blood vessels in the brain and heart increases from year to year. One of the most important factors that play a role in the blockage process is thrombosis. one way to assess platelet function is by examining platelet aggregation. The purpose of this study was to determine the results of the platelet aggregation test with a 1: 1 dilution of the specimen using physiological NaCl. Methods This research was conducted by examining platelet aggregation from specimens without dilution and by diluting the turbiditimetric method. Results: Analysis using the Paired test sample Sig. (2-tailed) $<0.05$ which indicates a difference between the results without dilution and with dilution. There are differences in the results of the study so that it is not recommended to dilute the platelet aggregation examination.

Key words: Platelet Aggregation, Without dilution, Dilution

Open Journal System (OJS): journal.thamrin.ac.id 


\section{PENDAHULUAN}

Frekuensi kematian akibat penyumbatan pembuluh darah di otak dan jantung meningkat dari tahun ke tahun. Salah satu faktor terpenting yang berperan dalam proses penyumbatan tersebut adalah thrombosis. Penyumbatan pembuluh darah otak dan jantung sering terjadi akibat hiperaktifitas dari fungsi trombosit. Hiperaktifitas dari fungsi trombosit tersebut mengakibatkan peningkatan kemampuan trombosit untuk menggumpal dan akan menimbulkan thrombosis yang menyumbat pembuluh darah, salah satu cara untuk menilai fungsi trombosit tersebut adalah dengan pemeriksaan agregasi trombosit.(maj.kedokt Indonesia, vol 57 no 7, juli 2007).

Pada pemeriksaan tes agregasi trombosit (TAT) hal-hal yang harus diperhatikan adalah volume spesimen darah sitrat yang harus sesuai SOP pemeriksaan TAT yaitu darah sebanyak 9,0

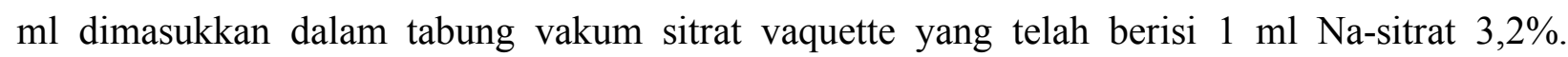
Kecepatan pemutaran saat proses pemisahan PRP (Platelet Rich Plasma) adalah 1000 rpm selama 15 menit atau 100 g selama 15 menit dan $\mathrm{pH}$ dari PRP. Karena pH pada pemeriksaan TAT sangat sensitif antara 7,2 - 8,0, bila $\mathrm{pH}$ dibawah 6,4 trombosit akan sulit beragregasi sedangkan bila $\mathrm{pH}$ diatas 8,0 dapat terjadi agregasi spontan. Karena perubahan $\mathrm{pH}$ terjadi melalui difusi CO2 dari plasma maka tabung PRP harus ditutup.

Untuk mendapatkan spesimen dari pasien yang mengalami penyumbatan pembuluh darah di otak dan jantung bukan hal yang mudah. Sering kali kita harus melakukan pengambilan spesimen yang berulang terutama untuk pemeriksaan TAT.

Berdasarkan hal tersebut diatas penulis tertarik untuk melakukan penelitian pemeriksaan agregasi trombosit tanpa pengenceran dan pengenceran spesimen 1:1 menggunakan $\mathrm{NaCl}$ fisiologis.

\section{METODE}

Penelitian dilakukan di Laboratorium Rumah Sakit Premier Bintaro dengan pengambilan data dari Juni sampai Agustus 2018. Populasi adalah pasien yang melakukan pemeriksaan agregasi trombosit di Rumah Sakit Premier Bintaro. Sampel adalah hasil agregasi trombosit dengan pengenceran specimen 1:1 di Rumah Sakit Premier Bintaro. Besar sampel dihitung menurut hukum rule of thumb dimana jumlah sampel minimal adalah 30 untuk semua kelompok. pemeriksaan TAT tanpa pengenceran dan dengan pengenceran specimen. perbandingan hasil dari hasil tanpa pengenceran dengan hasil pengenceran. Diperiksa pada Alat Aggregometer 
(Chrono-log model 490), data dilakukan analisi melalui uji paired t sampel untuk mencari hubungan antara dua variable yang memenuhi syarat analisa parametrik Batas penerimaan kesalahan ditetapkan 0,05 $(\mathrm{P}=0,05)$.

\section{HASIL \& PEMBAHASAN}

Penelitian ini diawali melihat gambaran distribusi frekuensi pada variable independen dan variable dependen yang di teliti. Analisa univariat menggambarkan distribusi dari jumlah pasien dan jenis kelamin, usia serta hasil pemeriksaan agregasi trombosit tanpa pengenceran dan pengenceran dengan $\mathrm{NaCl}$ 1:1. Selanjutnya hasil univariat akan dijelaskan pada sub bab berikut ini:

Jumlah pasien pada penelitian ini sebanyak 33 pasien dengan jenis kelamin laki- laki dan perempuan yang memeriksa TAT dari Juni - Agustus 2018 dengan distribusinya terlihat pada tabel

Distribusi Frekuensi dari jumlah pasien yang berjenis kelamin laki-laki dan perempuan

Tabel 1

Distribusi frekuensi pasien Agregasi trombosit berdasarkan jenis kelamin

\begin{tabular}{ccc}
\hline Jenis kelamin & Jumlah(n) & Prosentase(\%) \\
\hline Laki-laki & 11 & 33.3 \\
\hline Perempuan & 22 & 66.7 \\
\hline Total & 33 & 100
\end{tabular}

(kurniati,2018)

Hasil analisa tabel 1 didapatkan bahwa dari total subjek 33 orang yang memeriksa Agregasi trombosit yang berjenis kelamin laki-laki 11 orang (33.3\%) dan perempuan 22 orang (66.7\%)

Distribusi usia pasien yang memeriksa Agregasi trombosit di RS Premier Bintaro dari Juni Agustus 2018 terlihat pada tabel 2 berikut ini: 
Tabel 2

Distribusi frekuensi pasien Agregasi trombosit berdasarkan usia

\begin{tabular}{ccc}
\hline $\begin{array}{c}\text { Kelompok Usia } \\
(\text { Tahun })\end{array}$ & Jumlah (n) & Persentase (\%) \\
\hline$<45$ tahun & 13 & 39 \\
\hline$>=45$ tahun & 20 & 61 \\
\hline Jumlah & 33 & 100 \\
\hline
\end{tabular}

(Kurniati,2018)

Hasil analisa tabel 2 didapatkan bahwa dari total subjek 33 orang yang memeriksa Agregasi trombosit yang berusia dibawah 45 tahun berjumlah 13 orang (39\%) dan yang diatas 45 tahun 20 orang (61\%)

a. Hasil Agregasi Trombosit

1. Distribusi hasil Agregasi trombosit melalui kesimpulan hasil yang sama di RS Premier Bintaro dari Juni - Agustus 2018 terlihat pada tabel

Tabel 3

Distribusi frekuensi hasil Agregasi trombosit berdasarkan kesimpulan hasil yang berbeda dari

Tanpa pengenceran dan dengan Pengenceran

\begin{tabular}{rlllc}
\hline jumlah Hasil & TP & P & Persentase & $(\%)$ \\
\hline 1 & Hipo & Normo & 3 \\
\hline 11 & Normo & Hiper & $33^{\prime} 3$ \\
\hline Total & 12 & Hiper & - & 0 \\
\hline
\end{tabular}

(Kurniati,2018) Keterangan : TP : Tanpa Pengenceran P : Pengenceran

Hasil analisa tabel 3 menerangkan dari hasil pengerjaan yang memiliki hasil kesimpulan yang berbedadari 33 yaitu Hipo-agregasi (TP) menjadi Normo-agregasi (P) didapat sebanyak 1 pasien (3\%), Normo-agregasi (TP) menjadi Hiper-agregasi (P) sebanyak 11 pasien (33.3 \%) sedangkan hasil Hiper-Agregasi (TP) belum ada hasil yang berbeda pada hasil yang menggunakan pengenceran $(0 \%)$. 
Tabel 4

Distribusi frekuensi hasil Agregasi trombosit berdasarkan Adenosin Difosfat (ADP) tanpa pengenceran dan Pengenceran 1:1

\begin{tabular}{|c|c|c|c|c|c|c|c|c|}
\hline \multirow{3}{*}{ Variabel } & \multicolumn{8}{|c|}{ Adenosin Diphosfat (ADP) } \\
\hline & $\mathrm{TP}$ & $\mathrm{P}$ & TP & $\mathrm{P}$ & $\mathrm{TP}$ & $\mathrm{P}$ & $\mathrm{TP}$ & $\mathrm{P}$ \\
\hline & \multicolumn{2}{|c|}{1} & \multicolumn{2}{|c|}{2} & \multicolumn{2}{|c|}{5} & \multicolumn{2}{|c|}{10} \\
\hline Mean & 17,79 & 31.36 & 37.76 & 52.64 & 54.24 & 63.15 & 61.82 & 72.67 \\
\hline $\begin{array}{l}\text { Std. } \\
\text { Deviation }\end{array}$ & 19,63 & 21.08 & 22.00 & 23.23 & 19.74 & 21.30 & 18.20 & 20.02 \\
\hline
\end{tabular}

(Kurniati,2018) Keterangan : TP : Tanpa Pengenceran P : Pengenceran

Hasil analisa tabel 4 didapatkan bahwa dari total sampel sebanyak 33 pasien ( $100 \%$ ) memeriksa agregasi dan masing masing diperiksa dua kali tanpa pengenceran dan dengan pengenceran. Memiliki nilai rata rata pada ADP 1 tanpa pengenceran memiliki hasil rata-rata 17.79 dengan standar deviasi 19.63, sedangkan pada pengenceran hasil rata-rata didapat nilai rata-rata 31.36 dengan standar deviasi sebesar 21.08. Pada ADP 2 tanpa pengenceran memiliki rata-rata 37.76 standar deviasi 22.00 sedang pada pengenceran ADP 2 memiliki hasil rata-rata 52.64 standar deviasi 23.23. Pada ADP 5 tanpa pengenceran memiliki rata-rata 54.24, standar deviasi 19.74. sedangkan pada pengenceran ADP 5 didapat nilai rata-rata 63.15, standar deviasi 21.30. ADP 10 tanpa pengenceran memiliki nilai rata-rata 61.82 dengan standar deviasi 18.20. Pada ADP 10 dengan pengenceran memiliki nilai rata-rata 72.67 dengan standar deviasi 20.02. untuk mengetahui hubungan antara variable independen dan variable dependen. Analisis Bivariat dilakukan menggunakan uji Paired sampel t tes

\section{Tabel 7.}

Hubungan Agregasi Trombosit pengenceran dengan tanpa Pengenceran

\begin{tabular}{llc}
\hline Variable & & P Value \\
\hline Pair 1 & ADP 1_TP &, 000 \\
& ADP 1_P &, 000 \\
\hline Pair 2 & ADP 2_TP &, 001 \\
& ADP 2_P & \\
\hline Pair 3 & ADP 5_TP &, 000 \\
& ADP 5_P & \\
\hline Pair 4 & ADP 10_TP & \\
& ADP 10_P & \\
\hline
\end{tabular}


Dari tabel 7 tabel bivariat dari uji Paired sampel t didapat $\operatorname{sig}(2$ tailed) pada ADP1 $=0.000$, pada ADP 2 didapat $\operatorname{sig}(2$ tailed $)=0.000$, pada ADP 5 didapat $\operatorname{sig}(2$ tailed $)=0.001$ dan pada ADP 10 didapat $\operatorname{sig}(2$ tailed $)=0.000$, terdapat perbedaan yang signifikan dari hasil penelitian Agregasi trombosit tanpa pengenceran dan dengan pengenceran, yang berarti Ho ditolak

Dari hasil penelitian Agregasi trombosit yang telah dilakukan di Rumah Sakit Premier Bintaro didapat data-data yang disajikan pada tabel yang ada di bab IV ini.

Didapatkan jumlah data penelitian berjumlah 33 pasien yang setiap sampel dilakukan pemeriksaan dua kali yaitu tanpa pengenceran dan dengan pengenceran. Didapatkan hasil yang beraneka ragam kesimpulan hasil baik Hipo-agregasi, Normo-agregasi dan Hiper-agregasi yang dapat dilihat pada tabel 5 yang menjelaskan hasil yang berbeda sebanyak 12 pasien (36.3\%). Begitu pula pada hasil yang ditujukan pada tabel 6 menunjukkan standar deviasi yang besar pada setiap konsentrasi ADP baik yang tanpa pengenceran maupun dengan pengenceran.

Sedangkan pada tabel 7 menerangkan $\mathrm{P}$ value didapat dari data hasil uji paired sampel t yang menggambarkan adanya perbedaan yang signifikan dari hasil kedua spesimen yang dikerjakan tanpa pengenceran dan dengan pengenceran. Dari hasil agregasi trombosit tanpa pengenceran dan dengan pengenceran berdasarkan hasil kesimpulan dan dari hasil ADP ini dapat disebabkan karena adanya faktor dalam pengenceran dan sifat trombosit yang tidak stabil yang menyebabkan hasil memiliki perbedaan sehingga penelitian ini dapat memberikan gambaran dari hasil keduanya.

Penelitian yang dilakukan ini peneliti belum melihat adanya penelitian yang sama sebelumnya jadi peneliti tidak bisa membandingkan dengan hasil peneliti yang lain sebagai sumber rujukan. 


\section{SIMPULAN}

Terdapat perbedaan yang bermakna dari hasil yang didapat dari kedua cara yang dilakukan sebagai perbandingan. Karena terdapat perbedaan dari hasil keduanya sehingga tidak dianjurkan untuk dilakukan pengenceran pada spesimen TAT.

\section{UCAPAN TERIMA KASIH}

Penulis mengucapkan terima kasih kepada Kepala Laboratorium RS Premier Bintaro dan Prodi

D III Analis Kesehatan Fakultas Kesehatan Universitas MH Thamrin. dalam penelitian ini.

\section{DAFTAR PUSTAKA}

1. Chrono-log. Instruction manual for the Chronolog model 490 optical ' aggregometer. 1st ed. Leiden : Havertown.

2. Hoffbrand AV, Pettit JE, Moss PAH. Essential haematology. 4lh ed. Oxford : Blackwell Science; 2001.p.286-7.

3. Jurnal dari Prof Riadi wirawan. Nilai Rujukan Pemeriksaan Agregasi Trombosit dengan Adenosis Difosfat pada Orang Indonesia Dewasa Normal di Jakarta.

4. Jurnal dari Universitas Muhamadiyah Semarang.jtptunimus-gdl-suharyanti-6244-2bab ii

5. Suryaningsih V, Timan IS. Pemeriksaan agregasi trombosit dengan reagen ADP menggunakan alat PACKS-4. Bagian Patologi Klinik FKUI-RSCM. 1996. 
